\title{
Protein 4.1 Deficiency Associated with an Altered Binding to the Spectrin-Actin Complex of the Red Cell Membrane Skeleton
}

\author{
F. Lorenzo, ${ }^{\star}$ N. Dalla Venezia, ${ }^{*}$ L. Morlé, ${ }^{*}$ F. Baklouti, ${ }^{\star \ddagger}$ N. Alloisio, ${ }^{\star}$ M.-T. Ducluzeau, ${ }^{\star}$ L. Roda, ${ }^{\S}$ P. Lefrançois $\$$ \\ and J. Delaunay* \\ ${ }^{*}$ CNRS URA 1171, Institut Pasteur de Lyon, 69365 Lyon Cedex 07, France; ${ }^{\ddagger}$ Hematology Section, Department of Internal Medicine and \\ Human Genetics, Yale University School of Medicine, New Haven, Connecticut 06510; and ${ }^{\S}$ Centre Hospitalier, Annecy, France
}

\begin{abstract}
Protein 4.1 has been defined as a major component of the subcortical skeleton of erythrocytes. It binds the spectrinactin scaffold through a 10-kD internal domain. This binding requires an essential 21-amino acid sequence motif, Motif I, which is retained by alternative splicing at the late stage of erythroid differentiation. We here analyze the molecular basis of heterozygous $4.1(-)$ hereditary elliptocytosis, associated with protein 4.1 partial deficiency, in nine related French families. cDNA sequencing revealed a single codon deletion (AAA) resulting in a lysine residue deletion within the 10-kD binding domain, $3^{\prime}$ of Motif I. The mutated allele was designated allele 4.1 Aravis. In order to assess the functional effect of the codon deletion, recombinant $10-\mathrm{kD}$ constructs were made and various binding assays were performed using spectrin, purified spectrin-actin complex, or red cell membranes. These experiments demonstrated that the deletion of the Lys residue clearly prevents the binding capacity. Similar results were obtained with a construct containing the Lys residue but lacking Motif I. These data strongly suggest that the binding site to the spectrin-actin complex must contain the Lys 447 (or 448), and therefore resides not only on Motif I but extends 3 ' of this essential motif. (J. Clin. Invest. 1994. 94:1651-1656.) Key words: hereditary elliptocytosis $\cdot$ protein $4.1 \cdot$ codon deletion $\cdot$ red cell skeleton - genetic isolate
\end{abstract}

\section{Introduction}

Protein 4.1 is a major component of the red cell skeleton that strengthens the spectrin-actin lattice and contributes to the skeleton anchoring to the membrane via the cytoplasmic domains of transmembrane proteins $(1,2)$. Functional studies have established that the binding to the spectrin-actin complex of protein 4.1 resides in a $10-\mathrm{kD}$ internal domain $(3,4)$ (see Fig. 1 ).

The erythroid form of protein 4.1 is now known to be a

F. Lorenzo and N. Dalla Venezia contributed equally to this study.

F. Lorenzo's present address is Généthon, 1, rue de l'Internationale, BP 60, 91002 Evry Cedex, France. L. Roda's present address is Centre Hospitalier, BP 1640, Papeete, Tahiti. Address correspondence to N. Dalla Venezia, CNRS URA 1171, Institut Pasteur de Lyon, 69365 Lyon Cedex 07, France.

Received for publication 29 November 1993 and in revised form 11 July 1994.

J. Clin. Invest.

(c) The American Society for Clinical Investigation, Inc.

0021-9738/94/10/1651/06 \$2.00

Volume 94, October 1994, 1651-1656 member of a complex protein family that arises from a single gene by alternative mRNA splicing $(5,6)$. One particular splicing event involves a 21 -amino acid sequence motif, also called Motif I, the retention of which at the late stage of red cell development was found to be critical for protein 4.1 binding activity (7-12) (see Fig. 1). 4.1(-) HE designates a variety of hereditary elliptocytosis (HE) ${ }^{1}$ associated with a reduction or a virtual absence of protein 4.1 in the membrane, reflecting a heterozygous or a homozygous state, respectively (for review see reference 2).

Starting from previous studies on 4.1(-)HE (13), we delineated a small genetic isolate for a novel protein 4.1 variant, protein 4.1 Aravis. This variant lacked one lysine residue at position 447 ( or 448 ), in the $3^{\prime}$ portion of the $10-\mathrm{kD}$ domain. Various assays using recombinant $10-\mathrm{kD}$ domain established that the single lysine deletion abolishes the binding to spectrin, to the spectrin-actin complex or to the red cell membrane. These data, together with the genetic analysis of protein 4.1 Aravis carriers, suggest the lysine deletion to be the molecular basis of protein 4.1 deficiency.

\section{Methods}

Epidemiological, clinical, and routine biochemical studies. This investigation was initiated from a set of nine families with symptomless 4.1( - HE recruited on a random basis (13). These families failed to form a homogeneous group as shown by Northern blot analysis (13) and/or genealogical studies (14). Only four families, BE, BG, DU, and $G R$, were closely related. They resided in or originated from two valleys in the Aravis mountains (French Northern Alps). In view of a possible founder effect, we assumed that the present-day inhabitants of this area being of local descent for most of them, would exhibit an unusually high incidence of 4.1(-)HE. An epidemiological survey (blood smears) of school children showed that 6 children out of 155 (3.87\%) presented with $\mathrm{HE} \mathrm{(14).} \mathrm{To} \mathrm{establish} \mathrm{the} \mathrm{4.1} \mathrm{(}-$ ) nature of $\mathrm{HE}$, we assayed protein 4.1 (SDS-PAGE) in the parents displaying elliptocytosis, the inheritance pattern of elliptocytosis being dominant. Five additional 4.1(-) HE families were identified: BG2, BG3, GO, GP, and VD (see Fig. 2). They proved to be related to one another as well as to the four above families through a complex pattern of endogamy (14). Retrospectively, the mutation (described below) was recognized in all the kindreds from the cluster which could be reinvestigated in this respect. Taken together, a small genetic isolate for a particular 4.1( - ) allele has been outlined.

Furthermore, we screened the mutation (defined below) in a number of other 4.1 (-) HE families. Some were from the French Northern Alps, but failed to belong to the isolate; i.e., families BU, CA, LA, and PE (13), and family MI (unpublished results). Other families were from distinct areas: PA from France (15); SA from Spain (16); BO from Italy; and DA from Tunisia (unpublished results). Six normal controls

1. Abbreviations used in this paper: HE, hereditary elliptocytosis; GST, glutathione- $S$-transferase. 
Sense strand

I GC(GAATTC)GAAGGACTTGAAGAGTGCTCC (708-728)

III GC(GAATTC)GCCTGGAGAGCAAGAGCAGT (1544-1563)

V GC(GAATTC)GACAAGAGTCAAGAGGAGATC (2160-2180)

X GCA(GGATCC)AGAAGAAAAAGAGAGAAAGACTAG (2030-2109) XI GCA(GGATCC)AGGATTTAGACAAGAGTCAAGAG (2152-2174)
Antisense strand

II GC(GAATTC)TTGCCTGGTCTGAGCTTGAGT (1745-1725)

IV GC(GAATTC)AAGGGCAGAGTTGGGGTAGG (2774-2755)

VI GC(GAATTC)GGTGAGTGAGTGGATAAGCGT (2284-2264)

VII AGTGTGGACAATAGGGA (2426-2410)

VIII GGTGGCTCGTCTTCCTT (1996-1980)

IX ACGTGTCTCTGAAATCC (2591-2575)

XII GC(GAATTC)CCTCAAGTTCGGAAGGGTGAGTGAG (2294-2275)

Numbers in parentheses indicate the exact location of each oligonucleotide within the sequence published by Conboy et al. (6).

were chosen among non-HE members of several 4.1(-)HE kindreds or were individuals unrelated to any $4.1(-) \mathrm{HE}$ family.

Evaluation of protein 4.1 (based on SDS-PAGE and scanning of the stained gels) and Western blot analysis were performed as previously described or referred to $(13,17)$.

Studies on CDNA and genomic DNA. Total reticulocyte mRNA was prepared from peripheral blood as polysomal precipitates. $2 \mu \mathrm{g}$ of RNA were reverse transcribed and PCR amplified as previously described or referred to (18), using sequence specific primers (Table I and Fig. 1). In general, 30 cycles of amplification were performed (denaturation: $92^{\circ} \mathrm{C}, 60 \mathrm{~s}$; annealing: $60^{\circ} \mathrm{C}, 30 \mathrm{~s}$; extension: $72^{\circ} \mathrm{C}, 60 \mathrm{~s}$ ).

PCR products were analyzed on $3 \%$ Nusieve GTG gels (FMC BioProducts, Rockland, ME) and cloned into EcoRI-digested M13 mp 18 Vector (Pharmacia, Uppsala, Sweden). DNA sequencing was performed using specific primers (Table I and Fig. 1) or the M13 sequencing primer -40 (USB, Cleveland, OH). PCR-amplified cDNA was also digested with XmnI, or AlwNI (New England Biolabs, Beverly, MA), and analyzed on $3.5 \%$ Nusieve GTG gels (FMC BioProducts).

Genomic DNA was prepared from peripheral blood leukocytes according to standard procedures (including a ribonuclease A treatment of the leukocytes nuclei), or using the InstaGene Purification Matrix (Bio-Rad, Richmond, CA). 200 ng were PCR amplified as described above. The products were submitted to XmnI mapping and analyzed on 6\% Nusieve GTG gels (FMC BioProducts).

Purification of spectrin and protein 4.1. Preparation of red cell membranes was carried out as described before (17). Crude spectrin extract was obtained by washing the ghosts twice in $1 \mathrm{mM} \beta$-mercaptoethanol, $1 \mathrm{mM}$ EDTA, $0.3 \mathrm{mM}$ PMSF, pH 9.5 (with $\mathrm{NH}_{4} \mathrm{OH}$ ), and incubation for $30 \mathrm{~min}$ at $37^{\circ} \mathrm{C}(19)$. Under these conditions, the spectrin extract was devoid of protein 4.1 as assessed by Western blot. Protein 4.1 was extracted from spectrin-depleted vesicles with $1 \mathrm{M} \mathrm{KCl} \mathrm{(20)}$ and then purified by selective interaction with inositol hexaphosphate (21). Spectrin and protein 4.1 were dialyzed overnight against buffer A ( $130 \mathrm{mM} \mathrm{KCl}, 20 \mathrm{mM} \mathrm{NaCl}, 0.1 \mathrm{mM}$ EGTA, $10 \mathrm{mM}$ Tris, pH 7.4). Their concentration was estimated by Bradford assay (22).

Plasmid constructs and protein expression of the 10-kD domain. Primers X to XII (Table I and Fig. 1) were used to specifically amplify the 10-kD domain of protein 4.1 from a HE heterozygote. Four different fragments were generated by PCR. They will be referred to as $10 \mathrm{~K}(+\mathrm{I})$, $10 \mathrm{~K}(-\mathrm{I}), 10 \mathrm{~K}^{*}(+\mathrm{I})$, and $10 \mathrm{~K}^{*}(-\mathrm{I})\left({ }^{*} \mathrm{HE}\right.$ allele $)$, whether they con-

tain $(+I)$ or lack $(-I)$ Motif I sequence. The fragments were digested with BamHI and EcoRI, and cloned into pGEX-3X expression vector (Pharmacia). The constructs were fully sequenced to ascertain the absence of an additional sequence change that would result from the PCR experiments.

The four products were expressed in E. coli HB101 (GIBCO BRL, Gaithersburg, MD), as glutathione- $S$-transferase (GST) fusion proteins (23). Overnight cultures were diluted to 1:50 with Luria broth medium and grown to an $\mathrm{OD}_{600 \mathrm{~mm}}$ of 0.6. Isopropylthiogalactopyranoside was added up to $0.1 \mathrm{mM}$ and bacteria were grown for an additional $2 \mathrm{~h}$. Cells were harvested and resuspended in 1:50 culture volume of a lysis buffer containing $50 \mathrm{mM}$ Tris, $50 \mathrm{mM} \mathrm{NaCl}, 1 \mathrm{mM}$ EDTA, $0.15 \mathrm{mM}$ PMSF, pH 8.0 at $0^{\circ} \mathrm{C}$. They were treated for $15 \mathrm{~min}$ at $0^{\circ} \mathrm{C}$ with $2 \mathrm{mg} /$ $\mathrm{ml}$ lysozyme and for an additional $15 \mathrm{~min}$ with $0.2 \mathrm{mg} / \mathrm{ml}$ deoxyribonuclease I, $7 \mathrm{mM} \mathrm{MgCl}_{2}, 1 \%$ Triton X-100, $1 \mathrm{mM}$ PMSF. The GSTfusion proteins were purified from the lysates as previously described (23) using glutathione-Sepharose 4B beads (Pharmacia). Protein concentration was determined using the method of Bradford (22). The purity of the fusion proteins was assessed by $12.5 \%$ SDS-PAGE, and Western blot analysis using anti-protein 4.1 antibodies. Two minor bands ( 31 and $29 \mathrm{kD}$ ) copurified with the proteins containing Motif I (GST-10K $[+\mathrm{I}]$ and GST-10K*[+I]). They were identified as proteolytic products of the constructs as they were revealed by anti-protein 4.1 antibodies (not shown); the amount of the minor products increased upon storage at the reciprocal expense of intact constructs at $4^{\circ} \mathrm{C}$ (not shown).

Binding assays. Increasing amounts $(0.2-5 \mu \mathrm{g})$ of fusion $10-\mathrm{kD}$ domains (GST-10K $[+\mathrm{I}]$, GST-10K $[-\mathrm{I}]$, GST-10K* $[+\mathrm{I}]$, GST$\left.10 \mathrm{~K}^{*}[-\mathrm{I}]\right)$ were incubated with $10 \mu \mathrm{g}$ of spectrin for $1 \mathrm{~h}$ at $25^{\circ} \mathrm{C}$ in $50 \mu \mathrm{l}$ of binding buffer (buffer A containing $1 \mathrm{mM}$ EDTA, $0.5 \mathrm{mM}$ DTT). Each sample was then applied to a $3.5 \%$ polyacrylamide nondenaturing gel and electrophoresed as described before (24).

G-actin (Sigma Chemical Co., St. Louis, MO) was polymerized at a concentration of $1 \mathrm{mg} / \mathrm{ml}$ in $100 \mathrm{mM} \mathrm{KCl}, 2 \mathrm{mM} \mathrm{MgCl}, 0.2 \mathrm{mM}$ ATP, $0.2 \mathrm{mM} \mathrm{CaCl}_{2}$, and $10 \mathrm{mM}$ DTT at $25^{\circ} \mathrm{C}$ for $1 \mathrm{~h}$ before use. Binding assays were performed as previously described (4) with some modifications. $6 \mu \mathrm{g}$ of fusion $10-\mathrm{kD}$ domains were incubated with 10 $\mu \mathrm{g}$ of spectrin and $15 \mu \mathrm{g}$ of F-actin for $30 \mathrm{~min}$ at $25^{\circ} \mathrm{C}$. Incubation was continued for $1 \mathrm{~h}$ at $0^{\circ} \mathrm{C}$ in $110 \mu \mathrm{l}$ of binding buffer $(5 \mathrm{mM}$ phosphate, $0.5 \mathrm{mM}$ DTT, $2 \mathrm{mM} \mathrm{MgCl}, 0.2 \mathrm{mM}$ ATP in buffer A). $100 \mu \mathrm{l}$ of each

Erythroid protein 4.1

isoform

CDNA
Figure 1. Schematic representation of protein 4.1 cDNA. Functional domains issued from chymotryptic digestion are depicted on top. The location and size (bp, Arabic numerals) of the known motifs are indicated. $I$ designates the 21-amino acid sequence called Motif I. Oligonucleotides are denoted using roman numerals. 
sample was centrifuged for $30 \mathrm{~min}$ at $20,000 \mathrm{rpm}$ to sediment F-actin and associated polypeptides. Supernatant and pellet fractions were analyzed on $9 \%$ SDS-PAGE.

Competition assays of GST-10K $(+\mathrm{I})$ domain and purified native protein 4.1 for binding to the spectrin-actin complex were performed as described above, with the following modifications: the binding mixture contained a limiting amount of spectrin $(2.5 \mu \mathrm{g}), 5 \mu \mathrm{g}$ of F-actin, and $3 \mu \mathrm{g}$ of GST-10K $(+\mathrm{I})$ domain so that all the spectrin bound to the construct in absence of protein 4.1. Increasing amounts of protein 4.1 were added in a total volume of $540 \mu \mathrm{l}$, and $400 \mu \mathrm{l}$ was centrifuged for $2 \mathrm{~h}$ at $20,000 \mathrm{rpm}$. The pellets were analyzed by electrophoresis and scanned as mentioned above using actin as reference.

Incorporation of increasing amounts of fusion $10-\mathrm{kD}$ domains into freshly prepared red cell membranes was performed as previously described (25). A fraction ( $30 \mu \mathrm{l}$ ) of each sample was analyzed on $12.5 \%$ SDS-PAGE, and scanned as referred above using glyceraldehyde 3phosphate dehydrogenase (G3PDH) as reference.

\section{Results}

Protein 4.1 deficiency. Members of 8 out of the 9 related families were investigated at the protein level (Fig. 2). Consistent with previous studies $(13,17)$, a protein 4.1 deficiency of $\sim 30 \%$ was encountered in $13 \mathrm{HE}$ members $(11.91 \pm 1.00)$. Similar reduction (11.35 \pm 1.60$)$ was found in 14 HE heterozygotes from 8 out of the 9 kindreds not belonging to the isolate (See Methods) vs. $16.31 \pm 1.50$ in normal controls $(n=13)$. In all 4.1 HE heterozygotes, the reduction of protein 4.1 was significant $(P<0.01)$.

A single amino acid deletion defines allele 4.1 Aravis. Preliminary data obtained in family DU, belonging to the isolate, have suggested the absence of a gene rearrangement. Northern blot analysis failed to detect any qualitative or quantitative defect of the mRNA (13).

Two pairs of primers, I/II and III/IV (Fig. 1; Table I) were designed to amplify two overlapping regions of the mRNA encompassing the entire erythroid coding sequence. The resulting PCR products obtained in family GP were cloned and sequenced. No sequence change was found in the $5^{\prime}$ half of the cDNA. On the contrary, the $3^{\prime}$ region revealed a AAA codon deletion in 7 clones out of 12 (Fig. 3). This change results in the loss of a lysine residue from the $\mathrm{Lys}_{447}-\mathrm{Lys}_{448}$ tandem. (Amino acids were numbered according to Conboy et al. (6), and starting from the downstream AUG. However, the 57-bp motif, absent from the erythroid isoform, was not taken into account.) The abnormal allele was designated allele 4.1 Aravis.

The nucleotide sequence change generates an XmnI restriction site. Digestion of the PCR product (primers III/VI) yielded two fragments of 625 and $75 \mathrm{bp}$ instead of a 700-bp fragment (data not shown).

Protein $4.1 \mathrm{mRNA}$ was also amplified using primers I and VI. The resulting 1536-bp fragment was digested with XmnI. Fragments of 1,536 bp (normal allele) and of 1,461 and $75 \mathrm{bp}$ (mutated allele) were obtained (data not shown). These findings ruled out the presence of an additional alteration that would, in particular, have prevented cDNA priming with primer $I$.

Nucleotide sequencing revealed a GGA GCA GCT sequence (-Gly-Ala-Ala-) together with the expected sequence GGA GCA GCA GCT (Gly-Ala-Ala-Ala; positions 336-339) (6) (data not shown). The alanine skipping was observed in $20 \%$ of the sequenced clones. This modification abolished a AlwNI site, giving rise to a 697-bp product (primers III/IV), instead of 405- and 295-bp products (data not shown). It was

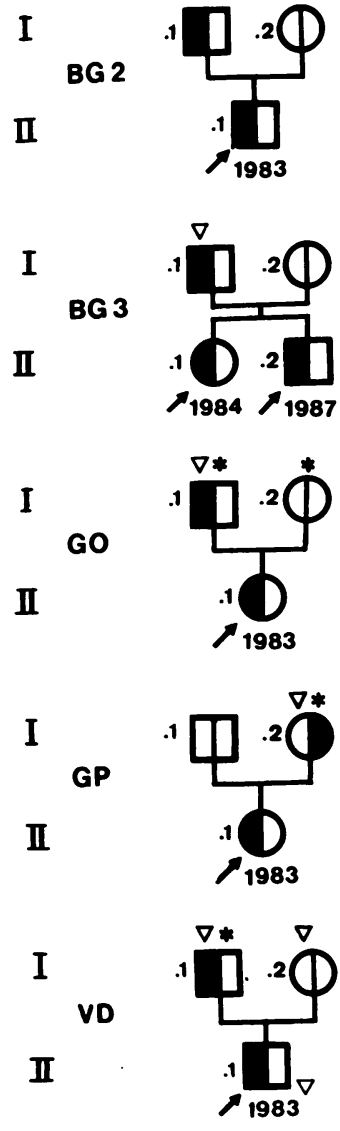

Figure 2. The pedigrees of the nine families forming the cluster. ( $\square$ ) Allele coding for normal protein 4.1. (घ) 4.1(-) HE allele as manifested by the presence of numerous elliptocytes in blood smears. Families of the left column have been presented before in detail (13). Newly detected kindreds appear in the right column: BG2, BG3, GO, VD, and GP (14). The probands $(\nearrow)$ were school children recognized upon an epidemiological survey. cDNA cloning was carried out in individual GP I.2. We indicated the members in whom SDS-PAGE of red blood cell membrane proteins $(\nabla)$ and/or screening of the mutation at the gene level $(*)$ were performed. (SDS-PAGE could not be performed in family BG2, but BG2 I.1 is the brother of BG3 I.1. Likewise, the screening of the mutation at the gene level could not be done in any of these two kindreds, however, both are closely related to family BG [left] that was fully investigated).

found in both the normal and the altered alleles. The present feature likely reflects an alternative splicing in the vicinity of an intron/exon boundary - tagcag/CA GCT instead of tag/CA GCA GCT (E.J. Benz, Jr., S.C. Huang, and F. Baklouti, unpublished data).

We tested the lysine codon deletion at the genomic level using XmnI digestion of PCR products. Primers V and VI designed within the same exon were used for PCR amplification (Fig. 3).

This AAA deletion was screened at the gene level in at least one 4.1(-)HE member from each of the 6 other families belonging to the isolate (Fig. 2). It was found in all 4.1 (-) $\mathrm{HE}$ heterozygotes. In contrast, it was encountered neither in 12 of the 4.1 (-) HE heterozygotes (from the 9 kindreds not belonging to the isolate, see Methods), nor in 6 non-HE controls.

Binding defect of protein 4.1 Aravis. Recombinant 10-kD 


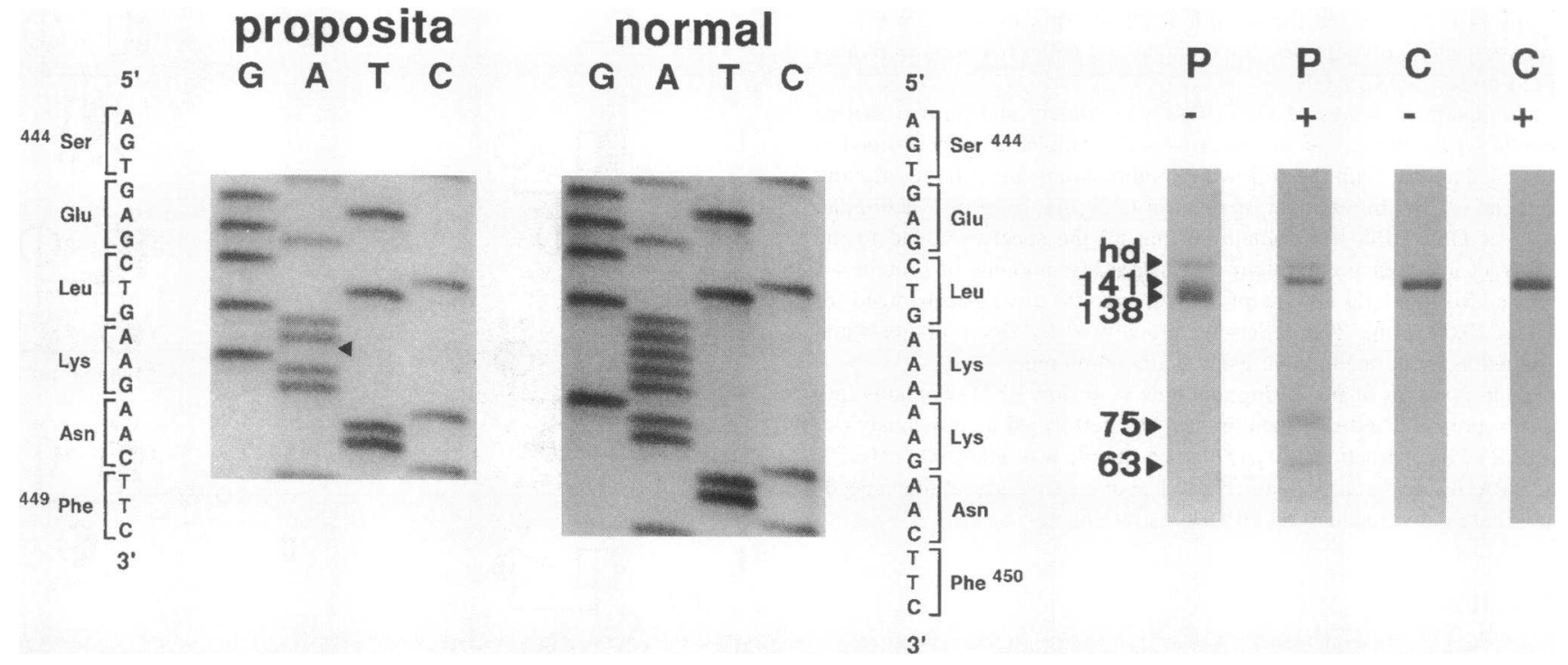

Figure 3. Protein 4.1 cDNA and genomic DNA analysis. (Left) Nucleotide sequencing of reticulocytes 4.1 cDNA clones. ( $\triangleleft)$ Lack of the AAA trinucleotide. (Right) Protein 4.1 genomic DNA was PCR amplified with primers V/VI. $(P) 4.1(-)$ heterozygote GP I.2; $(C)$ non-HE control; $(+$ and -$)$ presence and absence of XmnI enzyme, respectively. The fragment sizes are indicated (bp): $141 \mathrm{bp}$, normal; $138 \mathrm{bp}$, mutant, uncleaved; 75 and $63 \mathrm{bp}$, mutant, cleaved; $h d$, heteroduplexes.

domains were assayed for their binding to spectrin in a binary complex. Increasing amounts of GST-10K $(+\mathrm{I})$ construct were incubated with $10 \mu \mathrm{g}$ of crude spectrin and subsequently electrophoresed on nondenaturing polyacrylamide gel (Fig. 4). Only native free spectrin, mainly dimers and tetramers, would migrate whereas protein 4.1 -spectrin complexes remain trapped in the wells (24) (Fig. 4). The amount of free spectrin decreased in proportion as the quantity of GST-10K $(+\mathrm{I})$ domain increased. The minimum concentration of GST-10K $(+\mathrm{I})$ domain, required to complex all the spectrin molecules, was $1.8 \mu \mathrm{g}$. Constructs lacking Motif I (GST-10K [-I] and GST-10K*[-I]) did not bind to spectrin (Fig. 4), even at high concentrations (up to $5 \mu \mathrm{g}$ ). These findings were expected knowing that Motif I sequence is essential to the binding $(8,11,12)$. Remarkably, no binding was observed with GST-10K* $*$ I) construct which carries the lysine deletion (Fig. 4). Both GST alone and heatdenatured GST-10K $(+\mathrm{I})$ were unable to bind spectrin (not shown). These experiments suggested that the lysine deletion alters a sequence critical for the binary complex formation.
Ternary complex formation occurs when protein 4.1 , or its chymotryptic $10-\mathrm{kD}$ fragment, are added to spectrin and F-actin (4). A second binding assay, based on differential sedimentation, was performed with GST-10K $(+\mathrm{I})$, GST-10K $(-\mathrm{I})$, and GST-10K* $*$ I) constructs (Fig. 4). As expected, GST$10 \mathrm{~K}(+\mathrm{I})$ was the only product allowing the sedimentation of spectrin as a ternary complex. Binding experiments performed with GST-10K $(-\mathrm{I})$ or GST-10K* $*$ I $)$ domains generated the same pattern as with several negative controls (spectrin + actin, spectrin + GST-10K $(+\mathrm{I})$, or spectrin + actin + denatured GST-10K (+I)).

Competition assays of the GST-10K $(+\mathrm{I})$ domain and native protein 4.1 for the binding to spectrin-actin complex established that the construct mimics the native protein (Fig. 5); half of the GST-10K $(+\mathrm{I})$ domain was displaced by 0.5 mole equivalents of protein 4.1 , and up to $90 \%$ of the construct was displaced by a 5 mole excess of protein 4.1 . These results are quite similar to previous data using $10-\mathrm{kD}$ domain without GST (12).
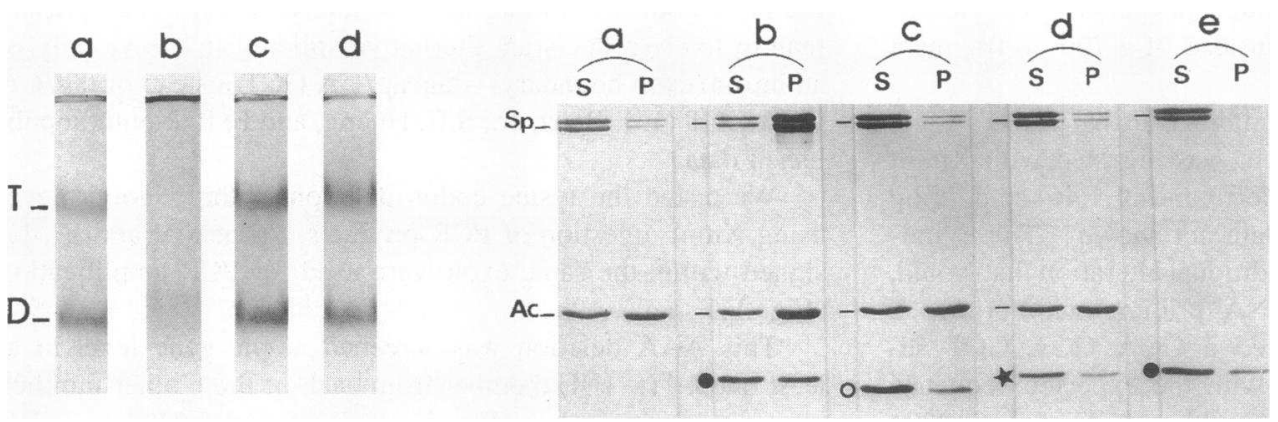

Figure 4. Binding assays of the $10-\mathrm{kD}$ domain of protein 4.1 to spectrin (left) and spectrin-actin complex (right). (Left) Nondenaturing gel electrophoresis of spectrin incubated with $10-\mathrm{kD}$ domain. (Lane $a$ ) spectrin (10 $\mu \mathrm{g}$ ); (lanes $b-d)$ spectrin $(10 \mu \mathrm{g})$ incubated with $5 \mu \mathrm{g}$ of GST-10K $(+\mathrm{I})$, GST-10K $(-\mathrm{I})$, or GST-

$10 \mathrm{~K}^{*}(+\mathrm{I})$, respectively. $D$, spectrin dimer; $T$, spectrin tetramer. (Right) Sedimentation analysis of spectrin-actin complexes in

the presence of 10-kD domain on SDS-PAGE. (Lane $a)$ spectrin (Sp) $(10 \mu \mathrm{g})$ incubated with F-actin (Ac) $(15 \mu \mathrm{g}) ;($ lanes $b-d)$ spectrin $(10$ $\mu \mathrm{g})$ and F-actin $(15 \mu \mathrm{g})$ incubated with $6 \mu \mathrm{g}$ of GST-10K $(+\mathrm{I})(\bullet)$, GST-10K $(-\mathrm{I})(0)$, or GST-10K * $(+\mathrm{I})(*)$, respectively; (lane $e)$ spectrin $(10 \mu \mathrm{g})$ incubated with GST-10K $(+\mathrm{I})(6 \mu \mathrm{g})$ in the absence of F-actin. $S$, supernatant; $P$, pellet. 


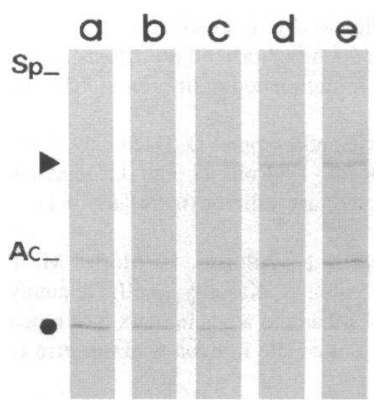

Figure 5. Competition of the GST$10 \mathrm{~K}(+\mathrm{I})$ domain and native protein 4.1 for the binding to spectrin-actin complex. (Lanes $a-e$ ) Spectrin $(S p)(2.5 \mu \mathrm{g}), \mathrm{F}$-actin $(A c)(5 \mu \mathrm{g})$, and GST-10K $(+\mathrm{I})(\bullet)(3 \mu \mathrm{g})$ were incubated with increasing amounts of protein $4.1(\bullet)(0,3.3,6.6,19.8$, and $33 \mu \mathrm{g}$ ) corresponding to $0,0.5$, 1,3 , and 5 mole ratios respectively. Pellets were resolved by SDS-

PAGE. In contrast with

binding conditions presented on Fig. 4 (right), a limiting amount of spectrin has been used.

To ascertain the binding defect of protein 4.1 Aravis to spectrin-actin complex in situ, incorporation of the GST$10 \mathrm{~K}^{*}(+\mathrm{I})$ construct into red cell membranes was assayed. Increasing amounts of GST-10K $(+\mathrm{I})$ and GST-10K $(-\mathrm{I})$ constructs were used as positive and negative controls, respectively. The GST-10K* $*$ + I ) did not associate to the red cell membranes (Fig. 6).

\section{Discussion}

After the recent description of allele 4.1 Madrid (16), harboring a point mutation in the downstream initiation codon, allele 4.1 Aravis is the second allele responsible of 4.1(-)HE to be defined at the gene level. It is likely that most mutations responsible for 4.1 (-) HE are private, being restricted to single families. The recurrence of allele 4.1 Aravis is the consequence of the endogamic structure of a community living in an isolated area (14).

The normal quality and quantity of total protein $4.1 \mathrm{mRNA}$ ruled out a major transcriptional or posttranscriptional defect. We therefore hypothesized that protein 4.1 Aravis was synthesized but was unable to bind to the membrane. The lack of binding of the construct GST-10K*(+I) to spectrin, the spectrin-actin complex and red cell membranes strongly supported this assumption. The absence of one lysine from the $\mathrm{Lys}_{447}$ Lys $_{448}$ tandem produces as drastic effects on the binding to the spectrin-actin complex as the lack of Motif I (construct GST$10 \mathrm{~K}[-\mathrm{I}]$ ). Therefore, the 21 -amino acid motif (position 407 to 427 ) is not the only part of the $10-\mathrm{kD}$ domain that is critical for binding to the spectrin-actin complex. Position 447 (or 448 ) also appears to be crucial in this respect. It belongs to an $\alpha$ helix (26) which may be disrupted by the absence of one lysine residue from the $\mathrm{Lys}_{447}-\mathrm{Lys}_{448}$ tandem.

It is noteworthy that this amino acid sequence is a highly conserved region among mammals (100\% sequence homology between human, mouse, and $\operatorname{dog})(27,28)$, avians $(95 \%$ sequence homology between human and chicken) (29), and amphibians (30); there is perfect conservation of the $\mathrm{Lys}_{447}-\mathrm{Lys}_{448}$ tandem among these species.

Unbound protein 4.1 Aravis must be rapidly degraded, even though Western blots did not evidence low molecular weight species in the membrane (13). The possibility remains that a small amount of protein 4.1 Aravis is present in the membrane. Subtle differences probably exist between $4.1(-) \mathrm{HE}$ alleles but they stand below the sensitivity threshold of SDS-PAGE analysis. In the present case, the absence of a single amino acid would result in the complete (or near complete) lack of mutated

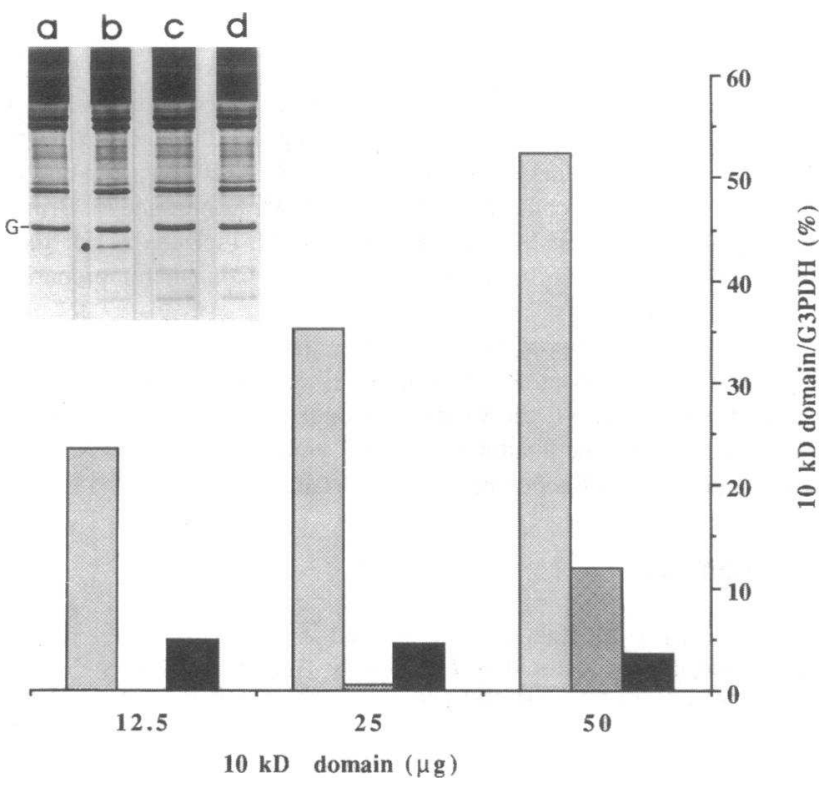

Figure 6. Incorporation of the $10-\mathrm{kD}$ domain to red cell membranes. $400 \mu \mathrm{l}$ of red cell membranes were incubated with increasing amounts

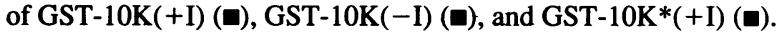
Samples were electrophoresed and incorporation of each construct was evaluated by scanning of the gel, using G3PDH as reference. Binding assay using $25 \mu \mathrm{g}$ of each construct is presented in the upper left inset. (Lane $a$ ) Red cell membranes; (Lanes $b-d$ ) red cell membranes incubated with GST-10K(+I) (๑), GST-10K(-I), or GST$10 \mathrm{~K} *(+\mathrm{I})$, respectively; $G, \mathrm{G} 3 \mathrm{PDH}$.

protein 4.1 , whereas a protein 4.1 variant, missing the 63 and 177 nucleotide motifs ( 31 ), was still able to be incorporated in the membrane (31). However, there is some evidence (31) that the amount of this truncated protein 4.1 was low, manifesting in a consistent fashion the binding defect.

Binding of protein 4.1 to nonspectrin proteins has been evidenced. Indeed, it is now established that $\sim 20 \%$ of protein 4.1 output contributes to the skeleton anchoring to the membrane, probably through an interaction of the $30-\mathrm{kD}$ domain with glycophorin $\mathrm{C}$ and p55 (32-34). Protein 4.1 Aravis contains an intact $30-\mathrm{kD}$ domain; therefore, one may assume that binding to nonspectrin proteins must be unaltered in this particular case. In fact, quantitative analysis, recently reported (34), has shown a slight p55 decrease in 4.1( - HE heterozygotes, including patients here found to carry 4.1 Aravis allele. To reconcile these conflicting findings, we may speculate that binding to the spectrin-actin complex is a prerequisite for binding to glycophorin $\mathrm{C}$ and p55. Alternatively, the lysine deletion may generate a secondary conformational change that also prevents an efficient binding of the $30-\mathrm{kD}$ domain to $\mathrm{p} 55$.

In this study, we identified a genetic isolate for 4.1(-) HE. Based on preliminary data, we have first ruled out a quantitative defect or a large deletion at the mRNA level. Subsequently, a AAA single codon deletion, abolishing a lysine residue within the $10-\mathrm{kD}$ domain, was consistently found in the 4.1 HE patients, thus defining allele 4.1 Aravis. Using various binding assays, we finally established that recombinant $10-\mathrm{kD}$ domain carrying this change was unable to bind to the spectrin-actin complex. 


\section{Acknowledgments}

We thank all the families for their generous cooperation; Drs. E. J. Benz, Jr. and S. C. Huang for communicating unpublished data; Drs. A. Iolascon, E. Miraglia del Giudice, and R. Kastally for providing us with some 4.1 (-)HE control samples; Drs. J.-M. Robert and G. Brunet for helpful discussions; Ms. S. Cavagna and M.-F. Barboza for their participation in the family studies; and Ms. N. Connan for preparing the manuscript.

This work was supported by the Association Française contre les Myopathies, the Conseil de la Région Rhône-Alpes, the Université Claude-Bernard Lyon-I, the Centre National de la Recherche Scientifique (URA 1171), the Institut Pasteur de Lyon, and the Institut National de la Santé et de la Recherche Médicale (CRE 930405).

\section{References}

1. Delaunay, J., N. Alloisio, L. Morlé, and B. Pothier. 1990. The red cell skeleton and its genetic disorders. In Molecular Aspects of Medicine. Volume 11, Number 3. H. Baum, J. Gergely, and B. L. Fanburg, editors. Pergamon Press, Oxford.

2. Conboy, J. G. 1993. Structure, function and molecular genetics of erythroid membrane skeletal protein 4.1 in normal and abnormal red blood cells. Semin. Hematol. 30:58-73.

3. Leto, T. L., and V. T. Marchesi. 1984. A structural model of human erythrocyte protein 4.1. J. Biol. Chem. 259:4603-4608.

4. Correas, I., T. L. Leto, D. W. Speicher, and V. T. Marchesi. 1986. Identification of the functional site of erythrocyte protein 4.1 involved in spectrin-actin associations. J. Biol. Chem. 261:3310-3315.

5. Tang, T. K., Z. Qin, T. Leto, V. T. Marchesi, and E. J. Benz, Jr. 1990. Heterogeneity of mRNA and protein products arising from the protein 4.1 gene in erythroid and nonerythroid tissues. J. Cell Biol. 110:617-624.

6. Conboy, J. G., J. Y. Chan, J. A. Chasis, Y. W. Kan, and N. Mohandas. 1991. Tissue-and development-specific alternative RNA splicing regulates expression of multiple isoforms of erythroid membrane protein 4.1. J. Biol. Chem. 266:82738280 .

7. Tang, T. K., T. L. Leto, I. Correas, M. A. Alonso, V. T. Marchesi, and E. J. Benz Jr. 1988. Selective expression of an erythroid-specific isoform of protein 4.1. Proc. Natl. Acad. Sci. USA. 85:3713-3717.

8. Tang, T. K., W. Horne, V. T. Marchesi, and E. J. Benz, Jr. 1989. Selective expression and function of exons retained or excluded from mature protein 4.1 mRNAs in erythroid and non-erythroid tissues. Clin. Res. 37:550a. (Abstr.)

9. Baklouti, F., T. K. Tang, S. C. Huang, and E. J. Benz Jr. 1992. Structure and utilization of exon/intron junctions of the protein 4.1 gene that are selectively utilized in erythroid and muscle cells. Blood. 80:273a. (Abstr.)

10. Chasis, J. A., L. Coulombel, J. Conboy, S. McGee, K. Andrews, Y. W. Kan, and N. Mohandas. 1993. Differentiation-associated switches in protein 4.1 expression; synthesis of multiple structural isoforms during normal human erythropoiesis. J. Clin. Invest. 91:329-338.

11. Discher, D., M. Parra, J. G. Conboy, and N. Mohandas. 1993. Mechanochemistry of the alternatively spliced spectrin-actin binding domain in membrane skeletal protein 4.1. J. Biol. Chem. 268:7186-7195.

12. Horne, W. C., S. C. Huang, P. B. Becker, T. K. Tang, and E. J. Benz Jr. 1993. Tissue-specific alternative splicing of protein 4.1 inserts an exon necessary for formation of the ternary complex with erythrocyte spectrin and F-actin. Blood. 82:2558-2563.

13. Feddal, S., G. Brunet, L. Roda, S. Chabanis, N. Alloisio, L. Morlé, M. T. Ducluzeau, J. Maréchal, J. M. Robert, E. J. Benz Jr., J. Delaunay, and F. Baklouti. 1991. Molecular analysis of hereditary elliptocytosis with reduced protein 4.1 in the French Northern Alps. Blood. 78:2113-2119.

14. Brunet, G., M. T. Ducluzeau, L. Roda, P. Lefrançois, F. Baklouti, J. Delaunay, and J. M. Robert. 1993. Diffusion of a particular 4.1(-) hereditary elliptocytosis allele in the French Northern Alps. J. Biosoc. Sci. 25:239-247.

15. Alloisio, N., E. Dorléac, R. Girot, and J. Delaunay. 1981. Analysis of the red cell membrane in a family with hereditary elliptocytosis. Total or partial absence of protein 4.1. Hum. Genet. 59:68-71.
16. Dalla Venezia, N., F. Gilsanz, N. Alloisio, M. T. Ducluzeau, E. J. Benz Jr., and J. Delaunay. 1992. Homozygous 4.1 (-) hereditary elliptocytosis associated with a point mutation in the downstream initiation codon of protein 4.1 gene. J. Clin. Invest. 90:1713-1717.

17. Alloisio, N., L. Morlé, E. Dorléac, O. Gentilhomme, D. Bachir, D. Guetarni, P. Colonna, M. Bost, Z. Zouaoui, L. Roda, D. Roussel, and J. Delaunay. 1985. The heterozygous form of $4.1(-)$ hereditary elliptocytosis [the $4.1(-)$ trait]. Blood. 65:46-51.

18. Baklouti, F., J. Maréchal, R. Wilmotte, N. Alloisio, L. Morlé, M. T. Ducluzeau, L. Denoroy, A. Mrad, M. H. Ben Aribia, R. Kastally, and J. Delaunay. 1992. Elliptocytogenic $\alpha^{1 / 36}$ spectrin Sfax lacks 9 amino acids in helix 3 of repeat 4: evidence for the activation of a cryptic 5 '-splice site in exon 8 of spectrin $\alpha$ gene. Blood. 79:2464-2470.

19. Lecomte, M. C., C. Galand, and P. Boivin. 1982. Protéines hydrosolubles des membranes érythrocytaires humaines. Différences de composition et de phosphorylation selon les conditions d'extraction. Nouv. Rev. Fr. Hematol. 24:349358.

20. Tyler, J. M., W. R. Hargreaves, and D. Branton. 1979. Purification of two spectrin-binding proteins: biochemical and electron microscopic evidence for sitespecific reassociation between spectrin and bands 2.1 and 4.1. Proc. Natl. Acad. Sci. USA. 76:5192-5196.

21. El Ouggouti, S., O. Bournier, P. Boivin, O. Bertrand, and D. Dhermy. 1992. Purification of erythrocyte protein 4.1 by selective interaction with inositol hexaphosphate. Protein Expression Purif. 3:488-496.

22. Bradford, M. M. 1976. A rapid and sensitive method for the quantitation of microgram quantities of protein utilizing the principle of protein dye binding Anal. Biochem. 72:248-254.

23. Smith, D. B., and K. S. Johnson. 1988. Single-step purification of polypeptides expressed in Escherichia coli as fusions with glutathione- $S$-transferase Gene. 67:31-40.

24. Garbarz, M., D. Dhermy, M. C. Lecomte, C. Féo, I. Chaveroche, C. Galand, O. Bournier, O. Bertrand, and P. Boivin. 1984. A variant of erythrocyte membrane skeletal protein band 4.1 associated with hereditary elliptocytosis. Blood. 64:1006-1015.

25. Takakuwa, Y., G. Tchernia, M. Rossi, M. Benabadji, and N. Mohandas. 1986. Restoration of normal membrane stability to unstable protein 4.1-deficien erythrocyte membranes by incorporation of purified protein 4.1. J. Clin. Invest. 78:80-85.

26. Conboy, J., Y. W. Kan, S. B. Shohet, and N. Mohandas. 1986. Molecular cloning of protein 4.1, a major structural element of the human erythrocyte membrane skeleton. Proc. Natl. Acad. Sci. USA. 83:9512-9516.

27. Huang, J. P., C. J. C. Tang, G. H. Kou, V. T. Marchesi, E. J. Benz Jr, and T. K. Tang. 1993. Genomic structure of the locus encoding protein 4.1; structural basis for complex combinational patterns of tissue-specific alternative RNA splicing. J. Biol. Chem. 268:3758-3766.

28. Conboy, J. G., R. Shitamoto, M. Parra, R. Winardi, A. Kabra, J. Smith, and N. Mohandas. 1991. Hereditary elliptocytosis due to both qualitative and quantitative defects in membrane skeletal protein 4.1. Blood. 78:2438-2443.

29. Yew, N. S., H. R. Choi, J. L. Gallarda, and J. D. Engel. 1987. Expression of cytoskeletal protein 4.1 during avian erythroid cellular maturation. Proc. Natl. Acad. Sci. USA. 84:1035-1039.

30. Giebelhaus, D. H., D. W. Eib, and R. T. Moon. 1988. Antisense RNA inhibits expression of membrane skeleton protein 4.1 during embryonic development of Xenopus. Cell. 53:601-615.

31. Marchesi, S. L., J. Conboy, P. Agre, J. T. Letsinger, V. T. Marchesi, D. W. Speicher, and N. Mohandas. 1990. Molecular analysis of insertion/deletion mutations in protein 4.1 in elliptocytosis. I. Biochemical identification of re arrangements in the spectrin/actin binding domain and functional characterizations. J. Clin. Invest. 86:516-523.

32. Leto, T. L., I. Correas, T. Tobe, R. A. Anderson, and W. C. Horne. 1986. Structure and function of human erythrocyte cytoskeletal protein 4.1. In Membrane Skeletons and Cytoskeletal-Membrane Associations. V. Bennett, C. M Cohen, S. E. Lux, and J. Palek, editors. Alan R. Liss, Inc., New York. 201-209.

33. Hemming, N. J., D. J. Anstee, W. J. Mawby, M. E. Reid, and M. J. A. Tanner. 1994. Localization of the protein 4.1-binding site on human erythrocyte glycophorins C and D. Biochem. J. 299:191-196.

34. Alloisio, N., N. Dalla Venezia, A. Rana, K. Andrabi, P. Texier, F. Gilsanz, J. P. Cartron, J. Delaunay, and A. H. Chishti. 1993. Evidence that red blood cel protein 555 may participate in the skeleton-membrane linkage that involves protein 4.1 and glycophorin C. Blood. 82:1323-1327. 